\title{
Political Economy in the Archaeology of Emergent Complexity: A Synthesis of Bottom-Up and Top-Down Approaches
}

Martin Furholt, Colin Grier, Matthew Spriggs, Timothy Earle

Corresponding Author

Martin Furholt

Department of Archaeology, Conservation and History

University of Oslo

P.O Box 1019, Blindern

$\mathrm{N}-0315$ Oslo, Norway

Tel. +4722841913

martin.furholt@iakh.uio.no

\section{Introduction}

Political economy approaches investigate how flows of labor and resources in the production of material items affect access to and use of those materials to support institutional power relationships among different social groupings. Such approaches offer an essential way to understand political relationships comparatively and provide a framework that we have found particularly useful for addressing anthropological problems that involve power and resistance to it. The most common political economy approach derives from Marx's emphasis on control of capital in modern states. When adapting his approach to archaic states and chiefdoms, the analytical focus has been top-down, considering how leaders come to and hold power (Ames 1995; Clark and Blake 1994; Earle 1997; Hayden 1995). As recently reviewed, chiefs and kings are seen as mobilizing surpluses to finance ruling institutions by creating bottlenecks with enforced property rights (Earle and Spriggs 2015; Earle 2017a; Kristiansen 2009). Current 
research in archaeology, however, has redirected attention to bottom-up approaches that critique this top-down approach, primarily because it pays insufficient attention to non-elite agency (Angelbeck and Grier 2012; Arnold et al. 2016; Blanton and Fargher 2008; Gintis, van Schaik, and Boehm 2015; Kienlin and Zimmermann 2012; McIntosh 1999; Robin 2013; Stanish 2017). Here, we argue that archaeological studies of power must integrate top-down and bottom-up perspectives on the construction of that power. We look at cases where chiefly powers are limited to particular scales and arenas of action. In these cases, an array of interacting agents, maneuvering within the structure of developing and established political economies, represent diverse interests and draw upon multiple sources of power at a variety of social scales (Blanton and Fargher 2008; Derlugian and Earle 2010).

Literature drawn from different perspectives describes these interacting and countervailing forces, demonstrating that they are fundamental to political economies, illuminating the ways that social power, resistance, and cooperation work concurrently, and how differing interests and objectives exist in perpetual tension. In this paper, these bottom-up forces are illustrated through three historically independent cases - Northwest Coast hunter-gatherer-fisher societies (case 1), early Neolithic expansions into Europe (case 2), and the Asia-Pacific region (case 3). In these cases, chiefly power was limited and much social action was possible outside their direct reach. As reviewed below, most political economy work has traditionally considered either fully developed chiefdoms or state societies. Our goal is, in contrast, to draw together relevant theoretical threads to conceptualize the complications of sociopolitical action in relatively smallscale societies where emergent hierarchies and inequalities are present. What follows is fundamentally a position paper that draws on existing evidence and well-published case studies to synthesize top-down and bottom-up perspectives within an integrated political economy 
approach. Our thesis is that political dynamics reflect dialectical relationships among diverse social agents, whose interests both conflict and overlap based on material conditions that structure labor and resource flows in societies.

\begin{abstract}
A historical perspective on political economy
As part of the $18^{\text {th }}$ Century Age of Enlightenment, political economy emerged from the field of social philosophy, seeking a rational analysis of society with the goal of critiquing its inequities and improving social outcomes. This goal has emerged and evolved over the past few centuries from the work of many scholars, but it is connected most centrally with Marx. A discussion of the classical political economy approach can be found in Earle and Spriggs (2015), and here we highlight elements of their discussion germane to our present goals.
\end{abstract}

The unifying element of political economy is that human societies are shaped by the material conditions of life and social relationships that underpin how economies work (Halperin 1989). Scholars like Adam Smith and Marx recognized that any economy is deeply embedded in society and social life, an idea elaborated in the mid-twentieth century by historical economist Karl Polanyi and his Substantivist school of economic anthropology (Bohannan and Bohannan 1968; Polanyi 1957). For Polanyi, economy and societal relationships are inextricably linked, and any universalizing of economic and social objectives, often expressed as the unwavering rationalism found in modern economic theory, should give way to more contextualized considerations of the strategies and goals of diverse actors. An important implication here is that political economies are more than the mobilization of surplus by elites for their own objectives, since not everyone shares the same goals or aspires for power or profits. 
Political economy has mostly focused on the economic organization of nation states (the 'polity' in political economy), looking at social outcomes of different economic structures on productivity, efficiency, social inequality and power. Marx's work offered a sharp critique of the way capitalist relations of production produced dramatically unequal outcomes across society, and his plan for radical and fundamental change to the capitalist mode of production emerged from that critique. Marx's striking solution was that the state must take substantial control of the economy by abrogating property rights of capitalists. With hindsight, marxist 'solutions', especially as realized in so-called communist nations, were hindered by a view of power primarily as a top-down phenomenon and by a narrow consideration of agency.

Following on Marx's initial observations, the history of political economy has included both topdown and bottom-up approaches. Anarchism, closely related to marxist thought, emanated from a similar critique of capitalist relations of production (Bakunin 1950 (1872); Marshall 1993). The two camps were distinguished by their approach, top-down versus bottom-up, which defined their respective ideas as to how to overcome capitalism. Marxists favored a top-down solution to the inequalities of capitalism involving state control of the economy (at least initially), while anarchists promoted local control over the economy. In this sense, and over-simplifying somewhat, the two revolutionary camps encapsulate top-down and bottom-up perspectives. Such differences in strategy and objectives have always existed within human societies, and we feel the study of prehistory offers the deep-time historical evidence to develop a balanced synthesis of political economy and its future possibilities. To do this, we must separate the theoretical concepts of marxism and anarchism from their political movements that set these theories in opposition to each other. 


\section{Moving political economy forward: braiding perspectives on power in prehistory}

Archaeology's increasingly refined methods, sustained investigations, and long-term perspective produce a rich corpus of knowledge on social change and stability. These data can form an empirical foundation for robust political economy approaches. To mobilize archaeological data, however, our theoretical tools need to be as sophisticated as our methodologies. So far, most archaeologists following a political economy approach have emphasized the actions of leaders (or those aspiring to rule), focusing on their abilities to control and dominate communities through coercion or persuasion, manipulation and bribery, and control of resources. The term 'top-down' refers to this one-sided analysis, positioning agency within dominating groups, while largely denying it to others. Such a focus has limited our conceptions of how societies operate as a dialectical process. Integrating a bottom-up approach is, therefore, primarily a project of relocating agency across broader social groupings, as well as recognizing self-organization into collectives and alliances that may counter elite domination. Non-elite agency can shape political systems by enabling, restricting, contributing to, or evading centralizing power.

Over the last two decades, non-elite perspectives have emerged from many strands of archaeological research. Reflecting a turn to post-modernism in the social sciences, inspired in part by Italian marxist Antonio Gramsci, archaeologists began looking at agency by the 'subaltern,' those thought to be excluded from power based on class, race, and gender (see Shanks and Tilley 1991). Brumfiel (1992) importantly advocated inclusion of broader social interests and factions to provide a more nuanced picture of how power and agency worked in past societies. More recent bottom-up approaches have investigated the complexity of agency inherent in households as well as peasant communities (Erickson 2006; Heckbert 2013). For example, archaeological studies focusing on the household unit have documented that most 
activities within families and their communities occurred independently of chiefly involvement (Blanton 1994; Robin 2013). To account for the nature of political systems fully, both top-down and bottom-up political agency should be situated in a dialectical relationship, as interdependent while at the same time potentially antagonistic. To braid their threads in pursuit of a synthesis, we draw on parallel trends in recent studies of anarchism, heterarchy, and collective action theory as applied to traditional states and non-state societies and review each briefly below.

Anarchism provides an explicit bottom-up approach to economic and political organization, focusing on the capability, even propensity, of individual actors to self-govern, self-organize, and cooperate in diverse groups and coalitions (Angelbeck and Grier 2012). In the tradition of anarchist thinkers like Bakunin (1950 (1872)) and Kropotkin (1972) and anthropologists like James Scott (1976, 1985, 2017), Pierre Clastres (1989) and David Graeber (2004), anarchist theory underscores how individuals and small groups build social networks to form decentralized organizations that stave off, resist, or undermine centralized political power.

Although aligned in many respects with marxist approaches (see for example, Hardt and Negri 2004), anarchist theory addresses low-level, local agency and processes, and how regional political organization can emerge from local scales of action. It stresses the human potential for cooperation, mutual aid, and empathy as structuring principles of society, rather than top-down hierarchies built on inequality. Anarchism posits five specific organizational principles that structure society and generate counter-movements to the concentration of power: 1) individual and local autonomy allowing for voluntary association, 2) mutual aid, 3) network organization that counters hierarchy, 4) communal decision making, and 5) acceptance of justified authorities and rejection of imposed power (Angelbeck and Grier 2012, 551). Most importantly, anarchist 
theory conceptualizes ways in which individuals, factions and communities self-organize to negotiate both compatible and disparate interests at multiple scales. Concern has typically been with smaller scales of community action that, in Clastres' famous phrase, can act as "a society against the state" (1989). Archaeological studies of 'house societies' provide a related approach to understanding political complexity without the centralization of power (Beck 2007). As shown below in our case studies, anarchism as a broad theoretical approach provides a framework to better understand the mechanisms of structural resistance to centralization within societies, as well as the means to resist encroaching state power.

Heterarchy is a theoretical approach outlining how un-ranked social units, variably ranked social units, or multiple social hierarchies can exist simultaneously, sometimes drawing on different sources of power. Rather than a single ruling hierarchical order, political power may be spread over multiple hierarchies from different clans, villages or tribal regions, as well as agegrade associations, religious cults, sodalities, crafting sets, and factions. With separate leadership, each social grouping operates, to some degree, to realize its own interests and common action. Crumley argues that heterarchies and hierarchies are not oppositional phenomena, but that they can coexist in societies (Crumley 1995, 4) such that elements of a system can be arranged in a wide array of configurations depending on context. This fluidity reflects Graeber's (2014) proposition that three basic forms of social interaction exist in every society: hierarchy, exchange, and 'baseline communism'. Inequality and authority in heterarchies are situational rather than structural, which is consistent with anarchist notions. Crumley and Graeber both argue that a plurality of different modes of political engagement exist, which reflect changing social contexts based on scale of organization, seasonality of activities, and 
personal motivations. Most importantly, the concept of heterarchy posits alternative organizational possibilities beyond the actions of centralized power.

Collective Action Theory (hereafter CAT) is a political economy approach that incorporates a strong bottom-up dimension (Blanton and Fargher 2008; Carballo 2013). In anthropology, communities have long been seen as self-organizing to solve local problems, but CAT seeks to expand this approach to consider institutional formations in regional polities (DeMarrais and Earle 2017). The importance of ritual institutions in such constituent (as opposed to coercive) chiefdoms suggests an especially religious mechanism for integration (Stanish 2017). Looking at state societies, sources of revenues determine the relative negotiating power of commoners. This is captured in Scott's (1976) phrase, "the moral economy of the peasant," in which compliance in agrarian states is based on guarantees of subsistence security with peasant rebellions as the corrective action. Similar to anarchism, CAT describes how groups at all scales and varied institutional forms (neighborhood cooperatives and coalitions, oligarchic association, and political parties) shape political systems by negotiating and resolving shared and competing interests. Collaborative groups, although lacking the institutional structure and resources of elites, can nonetheless negotiate with rulers for greater participation, better services, and more rewards. The negotiating power of farmers in a staple-finance state is based on their access to local productive resources, especially their own labor, and agricultural or ecological knowledge. The more bargaining power collectives have as a unified labor force, as tax-payers, and as functionaries, the more they can thwart or resist autocratic power to negotiate a range of social services including flood control, irrigation, road systems, religious ceremonies and protection from bandits (Blanton and Fargher 2008). These machinations affect how strategies of rule (corporate vs. exclusionary) developed (Blanton et al. 1996). The key point is that ruling 
institutions often depend on resources that they control only indirectly, such that the collective power of non-elite groups working those resources may balance control by elites. We embrace a major tenet of CAT that agency is spread broadly among individuals and groups positioned differently within the political economy.

In sum, marxism describes how dialectical tensions articulate social segments and their relationship to productive processes (McGuire and Saitta 1996). In a complementary and bottomup way, CAT shows how local communities can demand services from regional polities, while heterarchy points to multifaceted hierarchical and non-hierarchical ways by which actors organize their power relationships, and anarchism establishes alternative, decentralized principles through which they may be organized. Marxism's focus on dialectics provides a mechanism through which disparate components interact, and shows how their interactions produce social change (Saitta and McGuire 1998). “[E]ach household/individual ... is faced with a set of distinct and potentially conflicting ... interests and allegiances ..." (McGuire and Saitta 1996, 204); perpetual tensions between these interests and advocates produce long-term histories.

Despite some differences between the approaches and their goals, anarchist theory, heterarchy, CAT and marxist dialectics are complementary, even overlapping, and together provide a fertile alliance for building a synthesis within a political economy framework. Recognizing the multidimensionality to social strategies simultaneously expands views of agency, of interests and motivations for action and of opportunities for comparative analysis. While emphasizing historical processes, one goal of a political economy approach, as we see it, is to use the long- 
term histories visible through archaeology to generate a structural understanding (and critique) of economies and politics in our own world.

Such a program requires coming to terms with the depth of political creativity inherent in all societies (Wengrow and Graeber 2015; Rowley-Conwy 2001). Since at least the Upper Paleolithic, humans have demonstrated cognitive potential and ability to organize themselves in different ways, be it more egalitarian or more hierarchical, according to specific conditions and circumstances. Such a perspective also gives appropriate weight to the conscious and nuanced awareness of actors as to how the political systems in which they live fundamentally work. Humans appear intimately aware of possibilities inherent in different forms of social and political organization (Clastres 1989), and of how longer-term historical processes produce particular outcomes that reshape their interests and actions (Angelbeck and Grier 2012). Humans self-consciously make their own histories (Childe 1936).

\section{Towards a synthetic approach to political economy}

Our goal is to provide a framework for how dialectics of power relationships, conflicting institutional formations, and personal agency drive political creativity, and how these elements were engaged over the long term to generate histories. Drawing together convergent threads from multiple approaches helps mobilize a broader perspective on institutional complexity and agency. The concept of agency has focused on understanding how institutional structures and agents work in conjunction and in conflict to produce "big histories" (Robb and Pauketat 2013). In line with the approaches of CAT, we wish to avoid a simplistic agency/structure dichotomy and employ an actor-centered approach, in which divergent interests are continually negotiated. 
We seek to reconcile two modal dimensions inherent in any political economy analysis, one that illuminates general processes across historically independent cases and a second that emphasizes the specificity of individual societies and their complex histories. This reconciliation follows Marx's original conception of 'historical materialism' as a science set within a humanistic understanding. It captures dialectical tensions arising from top-down interests in creating control and accumulating wealth (marxist political economy), the intermediate compliance, collaboration, and negotiation of reciprocal relationships (CAT), and self-organization, resistance, obstruction, and subversion (anarchist theory). The simultaneity of these social phenomena and agencies (heterarchy) creates tensions and fuels social change through a dialectical process.

\section{Case Studies in Political Economy}

In a top-down approach, the emphasis is narrowly on variables and processes recognized in modern states, such as productive specialization, surplus extraction and social exploitation. We rather hope to create a more general political economy approach that unifies top-down and bottom-up approaches as appropriate for traditional polities with incipient or decentralized complexity. We present three cases that synthesize top-down and bottom-up dynamics, illuminating the historical specificity and general processes involved in political economies of societies without state-level integration. These cases highlight six elements of our model that we consider essential to a political economy approach to long-term social change:

1) Aspiring power: attempts by leaders to establish and expand central power.

2) Property rights: institutionalized control exercised over productive resources.

3) Collaboration and Balancing: cooperation to institutionalize domination by social groupings sharing interests. 
4) Resistance: autonomy of different social groupings to evade, obstruct, and co-opt the actions and authority of others.

5) Overlapping layers of action: multiple agency, discrete interests, and sociopolitical action to effect hegemony, resistance, and negotiation.

6) Embeddedness: linked to Marx's notion of historical materialism, historically-specific webs of political and economic interactions structure social relationships and create cultural meaning.

These six elements constitute fundamental organizational elements that provide a framework to understand the dynamics driving political processes in a way more balanced with regards to the diversity of different interests and agencies in any society. We do not generate a universal set of archaeological indicators for these six principles, since we expect that such indicators will be quite contextual and variable across case studies. We do expect that in many cases they will need to be evaluated creatively with proxies, since these principles are complex phenomena, being the product of overlapping layers of social negotiation and engagement. In the specific historic and prehistoric cases presented below, the indicators available to measure these elements in their respective records were of a different nature and quality, were more or less fine-grained, were subject to usual archaeological preservation biases and issues, and, because of their contextual nature, open to different degrees of ambiguity in interpretation. In the three cases explored here, we look at historically diverse settings and work at different scales, comparing transregional trends with more local, fine-grained considerations, adding to the issue by finding some common archaeological yardsticks.

Nevertheless, we do want briefly to outline some examples of how our six elements may be translated into a reading of ethnographic and archaeological indicators, drawing on some 
important and successful studies that have taken up similar approaches. Within the dynamics of social negotiations, the aspiration for power (Element 1) is materialized by some in accumulating wealth objects (symbolic capital), signs of bottlenecks in production and distribution, and the emergence of community-wide, even centralized institutions, which are visible in norms of house-building techniques, house placements, and material culture associated with houses. Alternatively, or in addition, aspiring power might show up in the construction of monuments, and the structure and equipment of burials (Earle 2017a).

Some forms of property rights (Element 2) are archaeologically better visible than others. Most importantly, the built landscape can indicate relations of uneven or exclusive access creating place-marked social divisions (Earle 2017b). We also discuss the role of complex technologies and their control in this regard.

Political independence of action can be observed among contemporary communities of similar scale (Sastre and Sánchez-Palencia 2013). Within a context of aspiring power and property control, to enact independence is resisting or evading power (Element 4), while it also enables actors to collaborate with or balance power relations (Element 3). When reconstructing a political economy, we look for resistance, collaboration and balancing in phenomena showing autonomy (e.g. of households, neighborhoods, settlement communities), decentralized networks as visible in material culture, in a ritual emphasis on equality reacting to earlier or contemporary signs of centralization, or in a proliferation of previously prestigious practices (e.g., Angelbeck and Grier 2012). Discussing these elements means acknowledging and disentangling the multiple overlapping layers of action materialized in the archaeological record (Element 5), and the historic specificity of cases (Element 6). 
Among the ethnographically-documented Coast Salish, a hereditary elite enjoyed

In the remainder of this paper, we present case studies from three historically independent world regions that have been integral to anthropological archaeology's research. Our goal is to consider these regions to advance points that we feel are central to a political economy approach. As such, we are not attempting to be comprehensive or definitive, but rather to highlight and synthesize how political economy engages aspects of each case. We intend our accounts to be complementary to those provided by other specialists working in these regions.

\section{Case study 1: Decentralized Networks in Coast Salish Political Development} For an initial application of our political economy approach, we turn to the huntergatherer-fisher societies of the Northwest Coast, focusing in particular on the Coast Salish region of southwestern British Columbia in Canada and northwestern Washington State in the United States. This case offers an opportunity to examine the role of topdown, bottom-up, and more horizontal practices in creating a decentralized, fluid sociopolitical structure. We draw primarily on the rich ethnographic record of the region, which provides a highly contextualized case to apply the theoretical principles (our six elements) central to a political economy analysis. Having developed over millennia, the prehistory of the Northwest Coast documents the long history of centralization and resistance.

\footnotetext{
significant wealth and privilege but only limited and localized political power in the face of countervailing interests and forces. Descriptions of Coast Salish politics indicate that
} 
these societies had "chiefs" (siem), but that the overarching political structures cannot be adequately characterized as chiefdoms, in which leaders wielded regionally-centralized authority (Angelbeck and Grier 2012; Miller and Boxberger 1994). The scale of chiefly authority was quite limited, primarily to multifamily households, creating a plethora of "house chiefs" within even a single village, which is a pattern seen in many regions of the Northwest Coast (Ames 1995).

A political economy perspective provides the framework in which we can understand how this specific organization emerged and was supported. The Coast Salish situation stemmed from both structural forms of resistance to centralized power and individual efforts to maintain household and individual autonomy (Angelbeck and Grier 2012). On the Northwest Coast generally, and in the Coast Salish region specifically, elite ("noble") class membership provided access to social privilege and material wealth unavailable to commoners (Ames 2008). Despite this, commoners exercised agency and maintained autonomy by choosing how and where to offer their labor. Much of this dialectic between elite control over labor and resources versus commoner autonomy was manifest at the household level, as part of the internal workings of large, multifamily households that incorporated individuals of varying social classes -- nobles, commoners and (potentially) slaves. As such, Coast Salish societies embody several of our key principles of political economy, and recent analyses of their practices over the last several millennia (e.g. Angelbeck and Grier 2012; Grier and Angelbeck 2017) highlight the utility of anarchist theory for clarifying how local practices were organized, providing a bottom-up example of agency and power distributed across different social groupings. 
As in many Northwest Coast cultural traditions, distant networks of affinal marriages were an important ethnographic feature of Coast Salish societies. These connections provided conduits, facilitated by seafaring watercraft, through which individual households connected with households in other communities to access extra-local social and material resources (Ames 1995; Suttles 1960). These networks are best documented in ethnographic sources but appear to have considerable antiquity. Archaeological evidence over several thousand years from the Coast Salish region indicates broad circulations of resources and people (Grier 2003). Such networks appear to have emerged initially as an adaptation to a regionally patchy mosaic of locally abundant resources, but by 2000 years ago, they take on a more political character, with an exclusive elite network of exchange the ethnographic noble class (Grier 2003). Elite symbols, including stone sculpture made of exotic material, circulated regionally, and shared practices, such as constructing sizable and elaborate burial mounds, came into existence. These elements became widely distributed in the $2^{\text {nd }}$ Millennium BP, likely as elites increasingly connected across the region while simultaneously excluding non-elites from access to status-reinforcing items and practices.

During the $2^{\text {nd }}$ Millennium BP, participation in regional elite networks hardened social difference and consolidated distinct social categories of people (elites vs. commoners, Angelbeck 2016) as the exchange of status and privilege-reinforcing symbols became increasingly restricted. Membership in the elite stratum was also marked through cranial deformation, by which elite status ascribed at or near birth was impressed for life on the physical body (Angelbeck and Grier 2012). The emergence of formally demarcated elites in part defines the Marpole period, components of which were in place by 2000 BP and persisted in the Salish Sea region over 
roughly a millennium.

Accounting for the exact timing of the transformation of distant social networks into elite defining mechanisms has been difficult. Lepofsky et al (2005) have argued that a climate trigger facilitated greater interactions focusing on the Fraser River system. Here, abundant and diverse resources were more predictable in the warmer period between 2400 and 1600 BP. Angelbeck and Cameron (2014) see new technologies as re-shaping political dynamics, particularly the autonomy of hunting with a lethal force accompanying the introduction of bows and arrows around 1600 BP. Grier (2014) argues that more formalized systems of property were key. The practice of terraforming to generate large-scale production features, especially shellfish compounds (clam gardens), fishing weirs, and managed plant gardens, probably served to consolidate increasingly unequal rights of access to property that were materialized in elite burials in large mounds. The occurrence of these practices accelerated in the millennium between 2000 and 1000 years ago (Grier et al 2017).

In many regions of the ancient world, regional networks and property relationships became increasingly centralized through time, as local elites expanded and consolidated power over larger areas by monopolizing flows of prestige and staple goods. Yet, in the Coast Salish region, and across the Northwest Coast, a regional political centralization did not occur, despite inherent choke points along rivers and ocean passages that apparently could have served to control the movement of resources (Clark and Blake 1994; Earle and Spriggs 2015; Schaepe 2009). At several junctures over the last 4000 years, elite power was ascendant (Angelbeck and Grier 2012; Coupland et al 2016), and 
settlement hierarchies did appear in the last millennium BP (Schaepe 2009). At some point, slavery began to provide labor for elite objectives, but when this commenced is currently unknown, despite some claims for its deep antiquity (Ames 2008; Grier 2018; Wengrow and Graeber 2018). Nonetheless, periods of elite ascendency were brought back into balance with bottom-up interests, both those of less powerful elites and of commoners. Tensions and shifts in power played out among Coast Salish over two millennia, in concert with shifting ecological, demographic and historical factors. But the central question remains - why did Coast Salish networks ultimately remain decentralized despite the existence of elites' with differential access to resources and surplus wealth?

We must look to the multiple ends that broad exchange networks served. First, these networks facilitated, through trade and negotiated arrangements, access to distant subsistence, social, political and symbolic resources. This likely occurred through much of the Holocene, creating complex regional relationships that stretched over hundreds of kilometers. Second, only a segment of these networks became exclusively controlled by elites and served to delineate and reinforce membership in an elite stratum. Third, and most importantly for an analysis of bottom-up processes, these networks simultaneously remained as a mechanism to circumvent centralization and regional control. If recent Coast Salish ethnography provides a guide, elite factions (effectively households) maintained kin-based affinal networks that could be individually drawn upon to avoid resource bottlenecks that might have been constructed by other elite factions. These affinal networks could be mobilized to resist efforts at centralization that involved force and coercion. The result was considerable household autonomy and political horizontality 
despite the marked wealth and status differences, and, later, the stratification of society into distinct social classes (Angelbeck 2009, 2016; Grier 2006).

As a result, formal intracommunity political structures were relatively limited. We have amongst the Coast Salish, and indeed throughout the Northwest Coast, few descriptions of formalized leadership positions at the village level. Most Salish ethnographers remark on the lack of political coherence of villages, except perhaps for the purpose of defense against external enemies and for ceremonies, when certain house chiefs might well come to the fore for specific and short-term ceremonial and political events, such as the renowned potlatch (e.g. Jonaitis 1991). But such hierarchical relationships would quickly halt as the objective of coordination ended. The Coast Salish region was an expansive territory in which multiple affinal networks could come together for specific purposes such as defense against external enemies (Angelbeck and McLay 2011). As such, horizontal networks served both for autonomy and for collective action, but not for centralization.

Elite-focused political dynamics played out in composite ways over the last two millennia (Angelbeck and Grier 2012), but regional politics were predicated on local economic fortunes of chiefs (Ames 1995, 2008). Political success of house chiefs depended on their ability to marshal labor to sustain their own households. In a single house, individuals of different social classes coordinated their action to produce and consume many resources (Ames 2008). Houses were corporate groups, central to Coast Salish society, typically drawing together closely related individuals, families and more distantly connected kin. Elites formed the core of these households (Ames 1995; Grier 2006), but their position 
was supported by the buy-in of commoners. Commoners could always vote with their feet, as the flexibility of kinship and co-residence in Coast Salish society provided them with many options to resist house chief authority.

The net result, recent and past, was a perpetual tension between social differentiation, collective action and autonomy (Coupland et al. 2009; Grier 2006). Similar tensions probably characterized many small-scale societies. Dialectical tensions between communalism and hierarchy apparently limited highly-centralized control within multifamily households, as each constituent family within a large household had considerable independence of action. Similarly, multiple, independent networks of household chiefs could circumvent efforts by any single chief or network to subjugate others, acting as a political levelling mechanism among elites. The critical dynamics that promoted decentralization and autonomy were that power and agency were distributed among many individuals with distinct interests and degrees of privilege. In these situations, non-chiefly agency was not simply a reaction to elite machinations but was strategic in its own right, both on the part of commoners and competing elites. Those with interests in putting a brake on centralization did not simply react to overt power grabs, they actively promoted structural limitations on centralization beyond individual households.

The Coast Salish case provides the opportunity to see how the six principles play out in a specific ethnographic situation with a long-term history. The emergence of elites and ultimately of a powerful elite class illustrates top-down machinations of power and property rights (Grier 2014), a point made by scholars working in many areas of the Northwest Coast. Collaboration and balancing are nonetheless integral for shaping the nature of power, in that affinal networks and autonomy of individuals of various social stations counterbalance the efforts of elites. From 
the household on up to the region, possibilities of resistance were realized at each scale. The historical embeddedness of processes is clear - certain resource structures and Salish-specific practices come into play, yet at the same time the case study shows broader alternative historical pathways on the Northwest coast and elsewhere, where decentralization remains dominant in political networks.

This last point may be the most critical for archaeological applications of political economy where ethnographic data are not available. Contrary to archaeological expectations that centralized settlement patterns and seats of regional chiefly authority necessarily follow the construction of bottlenecks by emergent elites, through a more balanced political economy perspective we see that alternative, bottom-up political structures can emerge. These patterns are discernable with appropriate attention to both top-down and bottom-up processes. We must also attend to the specifics of particular case studies, being careful to address the complexities of local and potentially unique processes, while providing a generalizable framework to guide analyses in other regions of the world (Grier 2018).

\section{Case study 2: Neolithic expansion into Europe: Voting with your feet}

After 8500 BP, the spread of early Neolithic populations into southeastern Europe (fig. 2) helps illustrate the utility of a synthetic political economy approach to emergent social complexity. The settling of people into anthropogenically altered and ordered landscapes effectively structured human behaviors socially and politically (e.g. Wilson 1991), and engineered permanent settlements made human relationships more clearly defined and potentially controllable by aspiring leaders. 
A main characteristic of Neolithic societies is delayed-return economies (e.g. Woodburn, 1982), in which labor is invested in animal breeding and fields, and harvests are stored for subsequent use. Some social regulation of access to both storage and improved productive facilities were probably linked to corporate groups. This transformation required a stricter definition of boundaries between social roles within and between communities, as well as a definition of property relations. This is often seen as contrasting to more fluid forager groups and their ethos of sharing associated with immediate-return forager economies (Peterson, 1993; Widlok, 2016; Woodburn, 1982). For this reason, the Neolithic has repeatedly been singled out as the phase when social and political inequality first arose (Childe, 1936; Price and Bar-Yosef, 2010). Property rights in resources and social exclusion connected to early Neolithic subsistence economies would have fueled more social dependency and probably laid the ground for political centralization and social stratification. Yet, the archaeological record suggests that this potential for centralization and stratification was not realized broadly for several millennia. With reference to case study 1 , what other social forces countered these trends?

During the initial establishment of Neolithic economies in Southwest Asia around 10,500 BP, the archaeological record suggests the beginning of more regulated social relations within communities. These are characterized by large, concentrated and spatially fixed settlements (Kuijt, 2008) resulting in tell formation (Rosenstock, 2009), indicating a permanent appropriation of place, and probably creating corporate property relations as found in many traditional communities to the present day (Earle 2017a). Considerable variability existed during this long-lasting emergence of Neolithic economies (Finlayson and Makarewicz, 2017), but generally increased structuring of space existed already during the Pre-Pottery Neolithic (PPN) of Southwest Asia and Central Anatolia. The household featured as a basic social unit within 
settlement-wide social institutions. Such institutions were effective enough to concentrate the placement of houses, visible in a clustered, pueblo-like layout, which potentially enabled stronger social control, visible in standardized house forms and building techniques (Cutting, 2005; Düring, 2011). As documented repeatedly by common patterns of building houses directly on top of previous ones, house positions were apparently established, representing tradition, heritage, and inherited property rights. Different forms of storage facilities have been broadly documented (Byrd, 1994; Kuijt, 2008). From early on, central storage suggests group management (Kuijt and Finlayson, 2009), but plant food was also stored in individual houses (Bartl, 2004; Bogaard et al., 2009). As Bogaard et al. (2009) argue for Catalhöyük, storage capacities in small and densely packed houses might well have sufficed for household consumption, but additional group storage probably existed for seeds to plant and to off-set unexpected short-falls. Also, animals had to be kept outside the settlement and were most probably defended in common. Wright (2014) adds another component, demonstrating that more costly tools, like large quern stones, were only present in some houses, suggesting early economic specialization and dependency.

Relating to the six elements of our political economy approach, we argue that the structural setting of the new Neolithic economy would favor those aspiring power. It is characterized by a) household-based property rights at least over plant resources, combined with b) a partial economic interdependence of households, c) central storage of surpluses, and d) effective social control through concentrated and regulated settlement space. In individual settlements, like Çatalhöyük, a concentration of symbolic capital in individual households (Hodder 2014) could have been translated by aggrandizers into individualized political power. Yet the archaeological record shows that this, if it happened in some places, was not widespread. 
Instead, aspiring would-be leaders were probably balanced and resisted by other social collectives within society. For example, Çatalhöyük and other central Anatolian sites feature a rather decentralized social organization visible in the architectural division into quarters or neighborhoods that suggests restraints on centralized power (Düring, 2011, p. 120; Hodder, 2014, p. 17). The political system possibly involved heterarchical decision-making from the household to the face-to-face neighborhoods to the entire community. At different levels of inclusion, elements of social balancing, fostered by the agency of social groupings would effectively have constrained elite segments (e.g. families, senior lines of inheritance tell settlements). Such balancing may have rested on principles of decentralization, or through an ethos of sharing between leaders and kin, or within bounded neighborhoods of 20-40 houses. We see an overlap between different collectives with potentially different interests, like the household, the neighborhood, lineages with different seniority and political power. The disparity between political power and economic distribution of resources could then have tempted senior lines to channel wealth in their favor, exacerbating contradictions within a continuing ethos of autonomy, horizontality and sharing.

\begin{abstract}
Although archaeologically obscured, outright resistance against social control may be reflected in segments of society spatially separated from the uniform settlement organization of villages, as seen for example in herder' mobility that allowed that segment to escape political authority (Makarewicz, 2013). However, the ultimate form of resistance is, in the same way as made clear for the other case studies, to leave a community and join another, or to form a new community in frontier forests and grasslands.
\end{abstract}


After $8500 \mathrm{BC}$, the political economy of early Neolithic communities of Western Anatolia and South-Eastern Europe is diverse relating to settlement concentration, overall regularity of settlement plans, or individual autonomy of households. But this diversity can be understood, we propose, by referring to tensions between social forces and their political negotiation power. The structural setting of Neolithic delayed return economies fostered a control of social space, in many cases leading to community-wide rules, control over which would have been contested between individuals and groups aspiring to centralized vs. more decentralized stances. Besides other possibilities of balancing and resisting the emergence of community-wide social control, and the resulting possibilities for centralization and accumulation of power, those wishing more household autonomy and/or an ethos of communality and sharing would, as an ultimate option, likely have looked for possibilities to escape by 'voting with your feet.' Where fertile soils were available in neighboring regions, and thus effectively limiting economic circumscription, fission was a workable means to assert bottom-up autonomy against emergent stratification, such as senior lineages claiming first rights to land (see Leppard, 2014). Several other authors have suggested this (Gilman 1981; Özdoğan 1997; Zilhão 2000), but we argue that, by putting it into the perspective of a synthetic political economy approach as dialectical, multi-agent political negotiations within Neolithic communities, it can be understood as a conscious social choice within a dynamic social system.

A comparable dynamic, with different historical outcomes can be studied in central Europe with early LBK settlement (7350-6900BP). Typical LBK settlements are small and dispersed, comprising of independent farmsteads (Lüning and Stehli, 1994). Colonization of Central Europe must have happened rapidly, between 7350 and 7300 BC (Jakucs et al., 2016). Following a few generations, larger settlement agglomerations appeared (Krause, 1998; Cladders et al., 2012; 
Furholt et al., 2014) with signs of settlement-wide social institutions, of hierarchical settlement patterns (Lüning and Stehli 1994), and of marked social inscription by enclosures and fortification (e.g. Furholt et al., 2014; Krause, 1998).

As a good example, the SW Slovakian Zitava valley was rapidly colonized by small, dispersed LBK settlements around $7300 \mathrm{BP}$, while an agglomeration process at the site of Vráble took place already by 7200 BP (Meadows et al. in press). Here, about 50 contemporary houses formed three neighborhoods of similar size, trapezoidal shape and orientation (fig. 3; Furholt et al. 2014; Furholt et al. in press; Müller-Scheeßel et al. in press). Like many other LBK settlements, Vráble consists of spatially fixed yards or farmsteads, where houses were built successively beside each other, only one or two being contemporary. This indicates, in a different, but equivalent manner than the tell settlements to the south, inter-generational claims to specific places, a piece of land - contemporary houses are regularly placed 80-100 meters from each other. The farmsteads were largely independent, as they showed distinct subsistence strategies, different animal and cultivated plant spectra, and produced household-specific pottery decoration patterns (MüllerScheeßel et al. in press). Storage was decentralized, with large, beehive-shaped storage pits associated with individual houses, spread evenly over the site. Between the farmsteads unequal access existed to critical materials, like lithic raw materials and especially Carpathian obsidian (Müller-Scheeßel et al. in press). Also, access to transregional networks was unevenly distributed. As LBK ornaments, Spondylus is often associated with social elite. The burial record of Vráble indicates several ritual categories attached to people, from a discard of human body parts in refuse pits, headless burials in a ditch without grave goods, to 'regular' LBK burials with one or two ceramic vessels, flint or obsidian tools. One male burial with six vessels and a large flint blade is located in the middle of the main enclosure gate. At $5100 \mathrm{BC}$, a double ditch and 
palisade enclosure system of $1.4 \mathrm{~km}$ was built around one of the three neighborhoods (Furholt et al. 2014). Around $4950 \mathrm{BC}$, the settlement was abandoned and replaced by small, dispersed clusters of four to five farmsteads during the Lengyel period.

Relating to our main elements of the political economy approach, the settlement agglomeration of Vráble created an opportunity for aspiring elites to strengthen their position. This is visible in the existence of an overall settlement spatial order, a feature well known from Southwest Asia and the Balkans, but unusual for an LBK context. Aspiring elites in this context might have drawn their status from the access to regional networks providing obsidian and spondylus. Farmstead-based property rights on land are indicated by spatial stability of farmsteads over the site's 300 years history. Top-down aspirations of emerging elites in the context of the establishment of settlement institutions was balanced and countered (or evaded) by marked farmstead autonomy, as well as intra-settlement neighborhood.

While obsidian and spondylus represent exclusive networks that help reinforce elite positions in local communities, the uniform pottery style of the LBK suggests more decentralized regional networks between farms, which, as we saw in case study 1, can effectively counter local centralization. The overall order of house placements in Vráble is less marked than in the Balkans or further south where close placement of houses and adherence to house rows show a more invasive power of community-wide institutions over household autonomy (Furholt 2016; 2017). Vráble, and indeed most LBK settlements, document strong regional networks and a relative lack of political coherence at the village-communities level, as we saw in case study 1 . As in that case, these suggest limited possibilities for top-down rule. 
Intermediate, corporate groups able to balance top-down aspirations can in Vráble, as parallel to the situation in Catalhöyük, be sought at the neighborhood level. Three contemporary, similarly sized settlement parts can be explained as representing an intermediate social group, between farmstead and village. These neighborhoods would probably consist of 15 to 20 farmsteads each, representing a social grouping that interacted in day-to-day personal contacts and thus formed a potential counter-weight against centralization efforts. Again, we can speak about an overlap between different collectives with potentially different interests in this village.

Over time, neighborhood identity in Vráble grew stronger, as can be seen in subsistence practices and material culture that are more similar within than between neighborhoods. In the later phase, a complex enclosure system was constructed (Furholt et al. in press); this costly, $1.4 \mathrm{~km}$ long delineation of one neighborhood had seven entrances, all facing away from the other neighborhoods and so restricting contact between them. Given that all three neighborhoods were still occupied during this period (Meadows et al. in press), an antagonism between these subunits seems evident. This enclosure was more than fortification; as with many other LBK enclosures, it was a place of complex ritual, sometimes violent activities, involving human bodies and body parts (Furholt et al. in press). Here, the differential categorization of people in these rituals (see above) indicates a historically unique complex, maybe even contentious negotiations. This negotiation was finally resolved by (or at least resulted in) social fission, Vráble's abandonment, except for very few houses with Lengyel material. After 6900 BP, the abandonment represents an apparent general re-dispersion of settlement through the region.

During the entire Neolithic period until the middle Bronze Age, centralized, hierarchical social systems only occurred episodically in Western Europe: In Carnac, around 6500 BP, complex and 
richly furnished graves in monumental burial mounds indicate the presence of a wealthy elite, possibly connected to Jadeite exchange (Pétrequin 2012). A little later, Passy-type graves in northwestern France might be interpreted in similar ways, and large enclosed settlements connected to the Michelsberg phenomenon could attest to a re-emergence of centralized settlement patterns (Gronenborn et al. 2018). At the same time as Carnac, in Varna at the Black Sea from 6900-6200 BC, richly furnished burials were associated with early copper and gold metallurgy found in densely built and internally structured tell settlements (Todorova 1978). In the $6^{\text {th }}$ millennium BP, well-structured megasites appear in the Northern Pontic area, in the context of the elaborate Cucuteni-Trypilla pottery (Müller et al. 2016). These of extremely large settlements appear to document top-down efforts of control, and centralization played out against bottom-up efforts of resistance. The reasons for this rebalancing of power are probably multiple and variable, but exploiting bottlenecks created by localized raw materials and connected technologies (jade, copper, gold, flints, obsidian, and probably salt) could well be important.

Yet none of these phenomena of social stratification and/or concentration of political power lasted long or fueled similar developments in neighboring regions, as later happened starting in the $5^{\text {th }}$ and $4^{\text {th }}$ millennium BP. Indeed, in the context of the 4500 years of Neolithic communities in Europe, emergent hierarchy seem to have been insulated and truncated. Possibilities for bottom-up and intermediate counter-balance and resistance appear to have existed.

As in our first case study and discussed for Catalhöyük and Vráble, Neolithic Europe prehistory indicates bottom-up agency and horizontal, decentralized social relations, countering and restricting top-down aspirations: the autonomy of households; social fluidity; and strong, decentralized networks, and the possibility of fission/secession. As their indicators take different 
forms and are present to different degrees in different periods and parts of Europe, we again concentrate on the early Neolithic in southeastern and central Europe.

First, the autonomy of households is well attested in the archaeological record. Even in Central Anatolia, after $8500 \mathrm{BP}$ in the course of the first migratory push westwards into Western Anatolia, house standardization ceased, suggesting enhanced possibilities for households to make independent decisions about size, building techniques, and placement (Pels, 2010; Marciniak et al., 2015). This individuality of choices is even more visible in Early Neolithic Greece (Souvatzi, 2008), the Balkans, and Central Europe. In the Balkans, Early Neolithic Starčevo settlements yielded few clear house structures, yet they seem each to be variable, and settlements, rather unstructured (Kozłowski and Raczky, 2010). Data documenting household autonomy are common in the LBK (Frirdich, 1994), despite standardized house forms. A constant tension appears to have existed between household autonomy and community solidarity in the Aegean (Halstead, 2006). Arponen et al. (2015) and Czerniak (2016) the re-emergence of household clusters and neighborhoods in Vinča and later LBK settlements (e.g. in Vráble, see above).

Second, high social fluidity strengthened bottom-up agency. Leppard (2014) argues for 'fragile communities', with a 'tendency towards community fission' as a strategy of alleviating social pressure that could lead to migration. Recent biomolecular investigations of early Neolithic populations in Central Europe reveal that community members show markedly variable individual lifeways (Zvelebil and Pettitt, 2013). Biological lineages of individuals buried at the same site, even those buried close to specific houses, are inconsistent (Brandt et al., 2014). Similar to case-study 1, flexibility in kinship and co-residence (Bentley et al., 2008) would appear to have provided individual choice of residence in alternative households. 
Third, decentralized social networks are a striking characteristic of the European Neolithic (Furholt, 2018). Although seldom recognized due to the legacy of culture historians being mainly interested in determining ethnic identities based on uniform styles in pottery and other objects, 'archaeological cultures' are in fact not self-evident. No 'Çatalhöyük Culture' existed, for example; this site was an isolated occurrence. By contrast, in later phases of Çatalhöyük, from $8500 \mathrm{BP}$ onwards, regional networks became decidedly more pronounced (Rosenstock et al., 2012). Red-on-white painted pottery stylistically linked both shores of the Aegean (Reingruber, 2011; Çilingiroğlu, 2012). The Starčevo and LBK cultures in Southeast and Central Europe also had strong trans-regional similarities in pottery technologies and style. As described in case 1, to keep broad styles relatively homogeneous across several generations must have required active maintenance of regional networks through inter-community mobility and exchange (Furholt, 2018); such decentralized networks could have provided protection against or balanced local efforts at political domination, especially when combined with household autonomy and social fluidity. Overlapping commoner and elite exchange networks (the latter concentrating on spondylus and copper) might be seen as conflicting with each other.

Finally, the option to leave a community and start anew at a previously unused spot of land would have represented a last resort for resistance against top-down aspirations during the Neolithic period. Voting with your feet might even have driven the expansion of Neolithic communities out of Anatolia and into Southeast and Central Europe, or led to regional dispersion processes as in the case of Vráble and the Zitava valley. 
Overall, the possibilities for top-down domination, while present, were effectively countered during the whole Neolithic and Copper Age Period, albeit in different ways and in different historical circumstances. In Anatolia, clear signs of stratification, like palaces and extremely rich graves, appear as early as the early $5^{\text {th }}$ millennium BP (Palumbi, 2012); in Greece (Younger and Rehak, 2008) and Spain (Lull et al., 2011) they are present by the $4^{\text {th }}$ millennium BP. In the rest of Europe, a lasting political and social stratification also appears by the $4^{\text {th }}$ millennium BP, although they are represented only by a limited number of outstandingly rich burials (Earle et al., 2015); no palaces or exalted chiefly houses, however, are known. Also, no larger population agglomerations are found; rather a system of autonomous farmsteads existed, especially in the northern part of Europe.

Kristiansen (2010) talks about 'decentralized complexity', accounting for the strength of bottomup and horizontal agency characterizing this variant of political systems, which maintained a strongly open ranking. Characterized as a 'Germanic Mode of Production', individuals and households retained a high degree of agency, and top-down elite domination was problematic and short term (Ling et al. 2018). In temperate Europe, chiefdoms appeared at a time when the strongest structural support of bottom-up resistance - the availability of unused fertile land suited for agriculture - ceased to be an option.

The expansion of agricultural communities into southeastern and Central Europe can be viewed as a multi-factored process, which played out in different ways in different places (Robb 2013). But it was, beside others, driven by factors foregrounded by our political economy approach. Top-down attempts to gain social control and centralized power were countered by intermediate sub-groups asserting agency to divert power aspirations and by bottom-up resistance building on 
and enhancing social fluidity and individual autonomy, self-organization, decentralization, and horizontal forms of organization. Critically important were both a fairly open (noncircumscribed) landscape and limited effective bottlenecks on commodity flows.

\section{Case Study 3: Migration as a safety valve across Island Southeast Asia and into the Pacific: Voting with your paddles}

Expanding upon an earlier political economy analysis of Pacific migrations (Earle and Spriggs 2015), we seek to understand the spread of the Island Southeast Asian Neolithic from Taiwan, through Island Southeast Asia, and into the Western Pacific. The contention is that the impetus for maritime colonization in these Neolithic societies was to escape growing structural inequalities, generated in part by the success of agricultural economies in supporting population growth with a relatively secure and easily expanded and/or intensified subsistence base. In circumstances of limited agricultural land, as characterized many Pacific islands, the potential for bottlenecks based on established property could allow elites to control agricultural surpluses (Earle and Spriggs 2015). As discussed in case 2, one way to counter incipient central power and inequalities, albeit a potentially traumatic one (Leppard 2014), is for community groupings to migrate out, either to areas of larger islands where population density was lower or - in the situation of Island Southeast Asia and the Western Pacific some 4000-3000 years ago - to shift the agricultural frontier south and east into archipelagoes where low-density hunter-gathererhorticultural populations were present and beyond these to uninhabited islands. The social dynamics driving the colonization process can be understood by a discussion of our six elements of a balanced political economy approach. 
One justification for this case study is to suggest future lines for research in a situation where the available evidence for many areas of this vast region is sparse. Using a combination of archaeological, historical linguistic and comparative ethnographic evidence from across the Austronesian-language area in a "triangulation" methodology (Kirch and Green 2001), a model can be constructed that generates hypotheses for future more detailed research.

The ancient societies being considered would have spoken Austronesian languages, whose general subgrouping has been reconstructed and from which information on ideology and social organization can be obtained by historical linguistic analyses (Blust 2013; Hage 1999a, 1999b; Pawley 1982). Referring to our first element, aspiring power, we use these linguistic insights to help build a model for early Austronesian social structure, based on a system of within-family primogeniture in preferential access to resources and rank, resulting in differential economic and political power between families, as particularly suggested by Hage (1999a). Useful general references to more detailed discussion of the archaeological evidence include Bellwood (2017) and Kirch (2017).

Distinct from case 2, Neolithic colonization of Island Southeast Asia and the Pacific (figs. 4 \& 5) had two special characteristics. Islands are the ultimate circumscribed landscapes and often subject to extreme environmental changes in coastal configuration and agricultural productivity that mean that, at least initially, they presented limited usable land, even when large in overall area (Spriggs 2010). The use of island land was thus likely to have been contested in terms of property rights. Only later did major engineering works of terracing and irrigation produce the engineered, productive landscapes that exist today across Island Southeast Asia and parts of the Pacific. Second, and counter to the first, was the maritime economy in which ownership of boats 
allowed for high mobility, an ability to 'vote with your paddles' in a situation where many uninhabited islands turned out to be available for settlement in the Pacific. Boats provided both this mobility but also distinctly different bottlenecks in the political economy. Because of the spatial separation of Pacific islands and the dangers of open sea navigation, sea-going vessels of large size were required to organize planned migrations and to carry viable communities to new homelands either singly or as parts of 'fleets'. During Island Southeast Asian and Western Pacific Neolithic, such boats were the most complex technologies found in the region. They were not the small, single-outrigger fishing canoes that can be seen in much of the Pacific today; indeed, few large voyaging canoes survived after European contact, and examples are found in only a handful of museums world-wide. Considerable resources, labor, and expert knowledge would have had to be mobilized for their construction and provisioning, and navigators and captains capable of keeping them afloat at sea were needed to bring them to suitable landfalls. Migrations would have demanded scouting beyond the horizon to assess possibilities for settlement, and carrying sufficient people, crops and domestic animals to establish viable economies (Irwin 1992). Any colonizing enterprise would have required substantial pre-planning and investment.

In terms of our political economy model, well-established, top-down power structures were potentially balanced and resisted by the possibility to organize colonization enterprises. Because of the particular geographic and technological circumstances, however, these were constrained in a way that necessitated collaboration of different agents, including leaders with access to social networks and material resources, skilled navigators, and potential settlers, for whom secession from their previous communities must have promised a reward justifying risk and effort. The 
experience of loss of people, including specialists and commoners, must have put pressure on the communities left behind, which increased bargaining power of 'stay-at-home' non-elite groups.

The colonizers were newly formed social groups with differential power and diverse interests. Within the Austronesian cultural milieu in Taiwan and elsewhere, the most likely leaders for colonizing groups would have been younger sons of established elite families within conical clans as reconstructed for early Austronesian society (Hage 1999b). Although these sons were never to inherit within the fixed kinship hierarchy with its "apical demotion" (Fox 1995, 223), they probably could have recruited sufficient resources, especially boats and crews, to undertake colonizing ventures. Skilled navigators and those engaged in other prestige practices (Spriggs 2016) must have had powerfully independent bargaining power within migrant groups that depended for survival on their skills. With monopoly-like situations, they might rival expedition leaders, serving to decentralize, delay or forestall emergent central power. Finally, disadvantaged, adventurous or disgruntled community members would also have joined up, and especially after arriving, their numbers must have given them a powerful bargaining position, especially after having experienced first-hand the possibility to organize and leave if their demands were dismissed.

We can see here the operation of several of our general principles: Aspiring power by younger sons of elite families, property rights in complex maritime technologies, and balancing of topdown power in the voyaging skills of navigators, crews and other specialists and a workforce needed to get people to new homes and to establish economically viable settlements. The lived experience of colonization must also have strengthened bottom-up empowerment, the possibility to resist. 
Early in the colonization process, the leader's links back to the 'homeland' and control of boat technology to maintain these ties may have been crucial to establish community viability by acquiring access to vital resources such as planting and breeding stock, marriage partners for small groups with unbalanced sex ratios, as well as necessary ritual and technological knowledge in unfamiliar environments. Access to needed technologies and social networks at a great distance across the horizon would have formed significant initial bottlenecks, allowing some consolidation of aspiring chiefly power (Earle and Spriggs 2015).

Once community economic autonomy was secured, however, after perhaps only a couple of generations, this justification for retaining hierarchical relations would have weakened, strengthening the hands of non-elite actors. Largely open lands would have made elite control problematic once a viable economy and secure population were established. Costs of noncompliance became low, and possibilities for autonomous decision making by non-elite actors were numerous. In short, resistance became a much more viable option. But as a full-land situation developed often in agriculturally limited environments, opportunities for more local, short-distance expansion may quickly have diminished, and apex family lineages would have produced their own generations of dissatisfied younger sons.

A potentially cyclical process thus existed following initial migration. For a while, elites controlled a maritime technology vital for community viability. Once the social and economic autonomy of colonizing groups were established, however, the bottlenecks promoting elite power weakened. They were only re-established once localized expansion options diminished as populations grew and new bottlenecks of land availability were created. Renewed long-distance 
migration would then be encouraged across what Pacific-scholar Epeli Hau'ofa (2008 [orig. 1993]) described as a 'sea of islands,' as interests coincided between dissatisfied commoners experiencing increased chiefly demands on labor and resources and those of lower ranked chiefly elites without traditional leadership options.

To illustrate this cyclical colonizing process, we first concentrate on the colonization of the Batanes Islands from Southeastern Taiwan (4200/4000BP) and then to northern Luzon (4000/3800BP) and then briefly discuss the colonization of the Western Pacific related to the Lapita Culture. After a migration from coastal China, somewhere between 6500-5000 BP, from 4800 BP onwards during Taiwan's Later Tapenkeng phase (TPK) (Hung and Carson 2014), rice and millet agriculture became associated with large villages on Taiwan's western plains. Initially, the island's 'frontier' was the east coast (Deng et al. 2017). The eastern plains were spatially restricted and soon reached some perceived demographic or social pressure after initially serving as the 'safety valve' for the now-densely populated west (Carson and Hung 2018). Around 4500 BP, east-coast sites suddenly increased seven fold and included settlements 20-30 times larger than previously (Hung and Carson 2014, 509). This growth must have caused "thresholds of stress" (Leppard 2014, 490), both demographic (cf. Deng et al. 2017) and social, the latter with potential bottlenecks enabled by agricultural intensification in a situation of limited agricultural land, prior to the later growth of eastern coastal plains associated with uplift and alluvial infilling.

Carson and Hung's (2018) case study is of one late-settled part of the eastern coast around Dulan Bay, where conditions would have discouraged settlement prior to about $4500 \mathrm{BP}$. The local Fushan culture sites are now at 40-50m above sea level on hilltops, but at the time of occupation 
they would have been near-coastal sites at about $5 \mathrm{~m}$ altitude with strictly limited agricultural potential because of no coastal plains, which developed later over a millennium or so. The limited agricultural land was a severe constraint, leading to settlement of the northern Philippines directly from the Fushan culture area (Carson and Hung 2018:795-99). Around 4200/4000BP, an exploratory push south occurred from southeastern Taiwan across a particularly treacherous sea reach to the Batanes Islands between Taiwan and northern Luzon. This was quickly followed c. 4000/3800 BP by colonists moving to Luzon's northern tip and penetrating south along the Cagayan Valley (fig. 4), where villages were established on alluvial and estuarine soil pockets (Carson and Hung 2018:799-802). Something beyond a solely demographic imperative is needed to explain this major colonizing move, however. The logistics of mounting colonizing expeditions would surely require chiefly direction as well as willing colonists prepared to take the chance.

Back in eastern Taiwan by about $3500 \mathrm{BP}$, what happens next is instructive as to the potentialities of the subsistence and social system once coastal plains developed there with rapid uplift, while the Fushan culture transitioned to the Peinan [Beinan] culture. The type site Peinan (3500-2300 BP) was the Çatalhöyük of Taiwan. Its layout echoes points made in case 2 concerning house standardization and structural layout. Originally estimated at 40-80 ha, more recent geophysical work suggests it could be up to 160 ha (Tong et al. 2013a; 2013b).

Houses were arranged in strict parallel rows with yards and rows of stone-walled storage houses or granaries between them. The house, yard and storehouse units were sometimes separated by stone walls perhaps delineating corporate social groups within the village (Bellwood 1997, 215). Burials were in stone cists below house floors, and adults were often accompanied by rich goods, 
with jade ornaments predominating. Clear social differentiation existed among burials regarding elaborateness of construction and quality and quantity of associated artefacts (Lien 1991, 2002). Standardized house forms and building techniques point to a spatial order similar to some early Neolithic Anatolian sites.

Current archaeological evidence shows a long-lived pattern of rebuilding houses indicating social stability, probably based on property rights and inequality between households as seen in differential burial wealth. Spatial divisions within the settlement suggest, however, more horizontally organized social grouping, that would have been able to counter or divert top-down aspirations, but also represented potential lines of conflict between groups. Nevertheless, it is easy to see why conditions for bottom-up resistance through fission could have arisen as nascent hierarchies developed with intensive rice and millet cultivation on newly-created east coast landscapes and were challenged by different, overlapping, horizontally arranged social groups. By this time northern Luzon would have been known as an overseas outpost of culturally closely-related groups, a potential haven for disaffected groupings of the population. The settlement pattern consisted of small rather dispersed settlements along rivers, such as Nagsabaran, Gaerlan, Irigayen, and Pamittan (Carson and Hung 2018: 800), which lacked signs of emerging hierarchies, as visible in Peinan. This situation seems similar to early Neolithic horizons in southeastern and Central Europe, as discussed in case study 2, and it corresponds with our model of colonizing groups as newly constituted social collectivities with more balanced power relations perhaps due to the bargaining power of both maritime and other specialists and commoners. 
By $3500 \mathrm{BP}$ at the latest, Neolithic populations had established coastal and riverine settlements across much of Island Southeast Asia, with sites in places such as the Karama Valley on Sulawesi mimicking the earlier settlement pattern of the Cagayan Valley of Luzon. Until about 3000BP, archaeological site density in the Cagayan and Karama Valleys was, however, not generally matched within broader Island Southeast Asia (Spriggs 2011).

\begin{abstract}
Austronesian colonization patterns become much clearer once islands were occupied east of New Guinea and into the western Pacific, perhaps significantly on islands that were in general considerably smaller than major Southeast Asian islands (see fig. 5). Termed the Lapita culture, initial Neolithic settlements eastward were open, coastal habitations (Kirch 1997). Pottery-using Neolithic populations of Southeast Asian origins established themselves first on less denselypopulated islands of the Bismarck Archipelago east of New Guinea in Near Oceania (Pawley and Green 1973, 5) and then quickly moved into uninhabited archipelagoes in Remote Oceania beyond the main Solomons chain. The Lapita culture is typified by elaborate dentate-stamped pottery, utilizing initially a tightly constrained design system including anthropomorphic head and mask motifs. This was the earliest pottery style across an area stretching from New Guinea in the west to Tonga and Samoa in the east. The wide distribution of Lapita Pottery must mark strong regional networks, which were, as the product of highly skilled specialists, evidently prestige items used to reinforce elite status (Earle and Spriggs 2015). As well as the pottery, Lapita was characterized by novel shell ornament types, standardized house forms, preferred coastal settlement locations, and transported domestic stock such as pigs and chickens and a range of agricultural plants (Kirch 2017). In later phases, production of elaborate Lapita pottery vessels declined and decoration on them simplified. Their function might have changed from
\end{abstract}


reinforcing elite status to a medium of non-elite networks, which strengthened intermediate and bottom-up possibilities, not least by tapping the previous high-status symbolism of such pots.

The aDNA evidence from Vanuatu and Tonga show the Lapita to have been generally unadmixed East Asians, whose closest living relatives today are northern Luzon farmers and Taiwanese aborigines (Skoglund et al. 2016). Beyond the initial Taiwanese outpost of the Cagayan Valley, the expansion must have outstripped demographic pressure, and the empowerment of the lived experienced of secession, as a possibility to resist domination became instead a socially-driven imperative as an 'ethos of moving on'. This ethos of exploration was doubtless backed by ideological justifications within the ritual sphere that encouraged migration (Spriggs 2016). Once uninhabited archipelagoes of the Reefs-Santa Cruz and Vanuatu were reached, colonization spread without pause into New Caledonia and Fiji and then onto Tonga and Samoa.

Towards the end of the Lapita period, in Vanuatu at least, the migration stream changed. New migrants, indigenous to the Bismarcks region swamped phenotypically the East Asian-derived Lapita population (Lipson et al. 2018; Posth et al. 2018), coinciding with cultural transformations ending Lapita . Burial rites shifted, the elaborate iconography of Lapita pottery rapidly simplified and then disappeared, and long-distance exchange ceased, thus ending connections back to the Bismarck Archipelago 'homeland'. Initially, post-Lapita settlements became larger and more permanent linear villages parallel to the coast, but, within a few hundred years, settlements shifted toward a more dispersed, increasingly inland pattern (Valentin et al. 2014). This postLapita shift was a "striking egalitarian turn" (Earle and Spriggs 2015, 523). It might have to do with secondary migrants from different socio-political backgrounds, but we want to highlight the 
reorganization of political structures during the colonizing experience, as one of the specifics of this case study.

Commoner resistance to elite power and the development of alternative forms of governance is well-illustrated in Vanuatu, where horizontal and anti-hierarchical forms persisted in many areas until European contact (Earle and Spriggs 2015, 524-5). Whether decentralization occurred as well at the end of Lapita in New Caledonia, Fiji and Western Polynesia is unclear with current evidence, but similar loss of long-distance interaction most certainly followed. By the next great migrations towards Eastern Polynesia 1500 years later, secondary migrations, similar to those into Vanuatu, must have already taken place in these archipelagoes according to currently available genetic evidence (Skoglund et al. 2016). Chiefs must have either disappeared or, as island populations rose and opportunities for local fission and expansion disappeared, elites must have been reestablished based on different bottlenecks (cf. Earle and Spriggs 2015).

Until recently, settlement of Island Southeast Asia and the Pacific has been seen from the topdown, led by brave navigator-chiefs who replicated and transformed pre-existing hierarchies from their homelands to become the chiefs of Contact-era Polynesia including prehistoric statelevel organization in the Tongan and Hawaiian Islands. The bottom-up desire to migrate beyond chiefly control and the new social dynamics unfolding in colonizing groups have not seriously been considered. Archaeologically we have had to find an explanation for extremely rapid colonization pulses across Island Southeast Asia and the Pacific, pulses inexplicable as simple reactions to demographic pressure but which required the use of large voyaging canoes, with the necessary mobilization of major resources for construction, crewing and successful landfalls and colonization. And yet, we also need to explain the 'egalitarian turn' seen in the archaeology of 
particular archipelagoes within a few generations of initial settlement by pioneering Neolithic groups, as hierarchies break down.

Stressing the significance of actions of those lower down in social hierarchies, a more balanced political economy perspective helps understand why these voyaging chiefs could recruit followers. Anarchist and related theories foreground the salience of such choices as relevant to many colonizers. Both commoners and putative leaders were disaffected, driven by a desire for a better life, but their ultimate aims were contradictory. Initially, hierarchies were maintained to establish new colonies linked back to established 'homelands'. How the apparent contradiction played out depended on further developments, including the roles played by subgroups including specialists, navigators and ritual practitioners, and, importantly, by the environmental potentials of particular islands - as Sahlins (1958) recognized over 60 years ago. Such social conditions and environmental constraints were mediated by distinct histories and varied forms of social mobilization, whether they were towards greater centralization or decentralization, towards greater hierarchy or a more communal ethic intent on guarding against just the social structures that people were intent on escaping. We see here the overlapping layers of action and the historical embeddedness delineated among our six elements of a political economy approach. These drove how the other four factors of aspiring power, property rights, collaboration and balancing and resistance played out.

\section{Prospects for a Unified Political Economy Approach to Emergent Complexity}

To summarize key points illuminated in the three case studies, a balance exists between topdown extraction and power consolidation versus bottom-up avoidance or even co-option of elite maneuverings, as in our final case study. Our last two case studies, dealing with comparable 
processes of Neolithic expansion, highlighted social fission in human history as a powerful means resist emerging social power. However, such an act creates a new social dynamic, and encapsulates seeds of contradiction between those aspiring to concentrate power and those trying to avoid it, forming a critical dialectic. This is most visible in case 3 where mastery and ownership of maritime seafaring technology is a prerequisite for breaking away. Case 1, with its rich ethnographic detail, clarifies how household units and individuals retain options of movement and support through active, decentralized networks of kin, marriage, exchange, and ritual association and how those networks counter local, elite-based attempts to gain political power. Such decentralized networks are archaeologically visible and can be identified in all cases through stylistic linkage and the circulation of objects and of people (as in Case study 2). The maritime technology bottleneck in Case 3, however, provides an added complexity. There, the shared iconography seen on Lapita pottery might equally be seen as reflecting links back to homelands that were initially critical in successful establishing colonies and in claims of those aspiring to power in new surroundings.

Although it must be admitted that archaeological patterns can always have alternative reasonable interpretations, the particular combination of elements that we highlight provides convincing support for our balanced model of agency, because they are logically consistent with a single theoretical position that requires new research for evaluation and refinement.

First, aspiring leaders appear in all. During Neolithic expansion, structuring of relationships of village life and regional relations were underpinned by agricultural intensification, for which improved fields and annual stored harvests had to be protected. Would-be chiefs could assert rights to surplus, as war and ritual leaders for instance, and use it to support political ambitions. 
Even without agriculture, similar conditions existed among intensive foragers (case 1).

Analogous to improved agricultural lands, constructed shellfish gardens, improved fishing facilities, and managed plant habitats represented capital improvements creating property rights and requiring defense. Sea-worthy boats, used for migration, trade and later for war, provided a potential bottleneck in case 3 .

Second, property rights emerged in the political economy of all cases. With settled life and capital improvements, farmers and complex foragers became tethered to places. As seen in the formation of stable village and house locations, human-resource bonds provided points of possible control. Even in mobile maritime societies, ownership of boats provided an alternative property regime. As inherent in political economy, emergent property relations structure how power became distributed.

Third, collaborating and balancing involved cooperation by social segments to further shared interests, as illustrated most clearly by the ethnographic details available for case 1 . Within a household, members also represented diverse statuses and interests that would sometimes be in conflict, but often would coincide. Colonizing and trading boat crews of the Pacific Islands illustrate how interests of chiefly boat owners, navigators, ritual specialists, and other migrants were distinctive and even contradictory, but the needs of the voyage and successful establishment of settlements in unfamiliar environments unified the group, at least in the shortterm. In Neolithic Europe, a similar dynamic is identified between households, neighborhoods and village community. 
Fourth, resistance was evident in the autonomy of various social segments and individuals, seeking to evade, obstruct, and co-opt the actions of others. In cases 2 and 3, colonizers voted with feet and paddles to avoid progressive extractions of labor and goods and the limitations of personal agency. Social organizations of colonizers were markedly less structured in regard to property and position. In case 1, families could move if local conditions were perceived as limiting. In all cases, the maintenance of decentralized networks was probably a conscious act to strengthen the possibilities of resistance to would-be chiefs, but control of the maritime technologies necessary to maintain such networks was an added complication especially in case 3.

Fifth, multi-scalar layers of action reflect interacting scales of organization. Coast Salish families did not have interests identical to their household, households within their communities, and communities within regional alliances. Colonization dramatizes how social groupings can strike out for a better life rather than continue an embedded life within established sociopolitical order.

And sixth, historical political and economic conditions led to case-specific outcomes. The importance of certain subsistence economies, technologies, and property rights in the LBK, Lapita and Salish examples provided particularities, within which more general political process operated.

Integrating the study of bottom-up and horizontal political actions with top-down strategies of control and centralization illuminates complicated dynamics involved in political economies and potential for synthesizing their many elements. Including balancing agencies and bottom-up 
resistance leads to fundamentally different social models and theory that deserve careful consideration in future research. Acknowledging the agency of commoners more explicitly, the diversity of overlapping forms of agency, and the complexity of political influence and alliances help to level the interpretative playing field. This enriches our understanding of all members of society, from rulers to specialists to everyday participants. Although insisting that economic relations and political organization are strongly interlinked, our synthesis does not predetermine which factors dominate. Rather, sources of power and authority were historically highly variable (Earle 1997). We argue for opening up the inquiry to allow, as an example, for colonization to be means for both domination and resistance. A concept of property should include a cultural sense of place at different scales, wide enough to include things, land, and resources (economic, social and religious in character) to which access was regulated by many social units. Agency exists at all social scales, from individuals, to households/or corresponding groups, residential units, and so on. Although power rests on economic conditions, each situation is unique, even if affected by general principles of behavior, agency and creativity. Humans make their histories (Childe 1936).

\section{References}

Ames, K.M. (1995). Chiefly Power and Household Production on the Northwest Coast. In T. D. Price \& G.M. Feinman (Eds.), Foundations of Social Inequality (pp. 155-87). Fundamental Issues in Archaeology. Springer, Boston, MA.

Ames, K.M. (2008). Slavery, Household Production, and Demography on the Southern Northwest Coast: Cables, Tacking, and Ropewalking. In C. Cameron, (Ed.), Invisible Citizens: Captives and their Consequences (pp. 138-58). Salt Lake City: University of Utah Press. 
Angelbeck, B. (2009). “They Recognize No Superior Chief”: Power, Practice Anarchism and Warfare in the Coast Salish Past. Unpublished PhD Dissertation, Vancouver, B.C.: University of British Columbia.

Angelbeck, B. (2016). The balance of autonomy and alliance in anarchic societies: the organization of defenses in the Coast Salish past. World Archaeology, 48 (1), 51-69.

Angelbeck, B. \& Cameron, I. (2014). The Faustian bargain of technological change: Evaluating the socioeconomic effects of the bow and arrow transition in the Coast Salish past. Journal of Anthropological Archaeology, 36 (Supplement C), 93-109.

Angelbeck, B. \& Grier, C. (2012). Anarchism and the Archaeology of Anarchic Societies: Resistance to Centralization in the Coast Salish Region of the Pacific Northwest Coast. Current Anthropology, 53 (5), 547-587.

Angelbeck, B. \& McLay, E. (2011). The Battle at Maple Bay: The Dynamics of Coast Salish Political Organization through Oral Histories. Ethnohistory 58 (3), 359-392.

Arnold, J. E., Sunell, S., Nigra, B.T., Bishop, K.J., Jones, T. \& Bongers, J. (2016). Entrenched Disbelief: Complex Hunter-Gatherers and the Case for Inclusive Cultural Evolutionary Thinking. Journal of Archaeological Method and Theory 23 (2), 448-499.

Arponen, V.P.J., Müller, J., Hofmann, R., Furholt, M., Ribeiro, A., Horn, C. \& Hinz, M. (2015). Using the Capability Approach to Conceptualise Inequality in Archaeology: the Case of the Late Neolithic Bosnian Site Okolište c. 5200-4600 BCE. Journal of Archaeological Method and Theory, 23 (2), 541-560.

Bakunin, M. (1950 [1872]). Marxism, Freedom and the State. London: Free Dom. 
Bartl, K. (2004). Vorratshaltung : die spätepipaläolithische und frühneolithische Entwicklung im westlichen Vorderasien; Voraussetzungen, typologische Varianz und sozio-ökonomische Implikationen im Zeitraum zwischen 12000 und 7600 BP. Berlin: ex oriente.

Beck, R. (2007). Durable House: House Society Models in Archaeology, Carbondale, IL: Center for Archaeological Investigations at Southern Illinois University.

Bellwood, P. S. (1997). Prehistory of the Indo-Malaysian Archipelago. Honolulu: University of Hawai'i Press.

Bellwood, P. S. (2017). First Islanders: Prehistory and Human Migration in Island Southeast Asia. Hoboken NJ: Wiley-Blackwell.

Bentley, R.A., Wahl, J., Price, T.D. \& Atkinson, T.C. (2008). Isotopic signatures and hereditary traits: snapshot of a Neolithic community in Germany. Antiquity, 82, 290-304.

Blanton, R.E. (1994). Houses and Households: A comparative Study. New York: Plenum Press.

Blanton, R. E., Feinman, G. M., Kowalewski S. A. \& Peregrine, P.N. (1996). A Dual-Processual Theory for the Evolution of Mesoamerican Civilization. Current Anthropology, 37, 1-14.

Blanton, R. \& Fargher, L. (2008). Collective Action in the Formation of Pre-Modern States. New York NY: Springer.

Blust, R. (2013). The Austronesian Languages (revised edition). Asia-Pacific Linguistics Open Access Monographs 8. Canberra: Asia-Pacific Linguistics, RSPAS, ANU. 
Bogaard, A., Charles, M.B. \& Twiss, K.C. (2009). Private pantries and celebrated surplus : storing and sharing food at Neolithic Çatalhöyük, Central Anatolia. Antiquity, 83, 649668.

Bohannan, P. \& Bohannan, L. (1968). Tiv Economy. Evanston: Northwestern University Press.

Brandt, G., Knipper, C., Nicklisch, N., Ganslmeier, R., Klamm, M. \& Alt, K.W. (2014).

Settlement Burials at the Karsdorf LBK Site, Saxony-Anhalt, Germany: Biological Ties and Residential Mobility. In A. Whittle \& P. Bickle (Eds.), Early Farmers. The View from Archaeology and Science (pp. 95-114). British Academy, Oxford,

Brumfiel, E. M. (1992). Distinguished Lecture in Archeology: Breaking and Entering the Ecosystem - Gender, Class, and Faction Steal the Show. American Anthropologist, 94 (3), 551-67.

Byrd, B. F. (1994). Public and Private, Domestic and Corporate: The Emergence of the Southwest Asian Village. American Antiquity, 59 (4), 639-66.

Carballo, D. (ed.) (2013). Cooperation and Collective Action: Archaeological Perspectives. University Press of Colorado.

Carson, M.T. \& Hung, H.C. (2018). Learning from Paleo-Landscapes: Defining the Land-Use Systems of the Ancient Malayo-Polynesian Homeland. Current Anthropology, 59 (6), 790-813.

Childe, G. (1936). Man Makes Himself. London: Watts

Çilingiroğlu, Ç. 2012. The Neolithic Pottery of Ulucak in Aegean Turkey : organization of production, interregional comparisons and relative chronology. Oxford: Archaeopress. 
Cladders, M., Stäuble, H., Tischendorf, T. \& Wolfram, S. (2012). Zur linien- und stichbandkeramischen Besiedlung von Eythra, Lkr. Leipzig. In M. Cladders, H. Stäuble, T. Tischendorf \& S. Wolfram (Eds.), Siedlungsstruktur Und Kulturwandel in Der Bandkeramik. Beiträge Zur Internationalen Tagung "Neue Fragen Zur Bandkeramik Oder Alles Beim Alten?!” Leipzig, 23.-24. September 2010 (pp. 146-159) Dresden: Landesamt für Archäologie.

Clark, J. E. \& Blake, M. (1994). The power of prestige: competitive generosity and the emergence of rank societies in lowland Mesoamerica. In E. M. Brumfiel \& J. W. Fox (Eds.), Factional Competition and Political Development in the New World (pp. 17-30). New Directions in Archaeology. Cambridge: Cambridge University Press.

Clastres, P. (1989). Society Against the State: Essays in Political Anthropology. Robert Hurley. London: Zone Books.

Coupland, G., Clark, T. \& Palmer, A. (2009). Hierarchy, Communalism, and the Spatial Order of Northwest Coast Plank Houses: A Comparative Study. American Antiquity, 74 (1), $77-$ 106.

Coupland, G., D. Bilton, T. Clark, J. S. Cybulski, G. Frederick, A. Holland, B. Letham and G. Williams (2016) A Wealth of Beads: Evidence for Material Wealth-Based Inequality in the Salish Sea Region, 4000-3500 Cal B.P. American Antiquity, 81(2), 294-315.

Crumley, C. L. (1995). Heterarchy and the Analysis of Complex Societies. Archeological Papers of the American Anthropological Association, 6 (1), 1-5.

Cutting, M.V. (2005). The Neolithic and Early Chalcolithic Farmers of Central and Southwest Anatolia, Britisch Archaeological Reports International Series. Oxford: Archaeopress. 
Czerniak, L. (2016). House and Household in the LBK. In L. Amkreutz, F. Haack \& D. Hofmann (Eds.), Something Out of the Ordinary? Interpreting Diversity in the Early Neolithic Linearbandkeramik and Beyond: Interpreting Diversity in the Early Neolithic Linearbandkeramik and Beyond (pp. 33-64). Cambridge: Scholars Publishing.

DeMarrais, E. \& Earle, T. (2017). Collective Action Theory and the Dynamics of Complex Societies. Annual Review of Anthropology, 46 (1), 183-201.

Deng, K., Yang, S., Li, C., Su, N., Bi, L., Chang, Y-P. \& Chang, S.-C. (2017). Detrital zircon geochronology of river sands from Taiwan: Implications for sedimentary provenance of Taiwan and its source link with the east China mainland. Earth-Science Reviews, 164 (Supplement C), 31-47.

Derlugian, G. \& Earle, T. (2010). Strong chieftaincies out of weak states, or elemental power unbound. Comparative Social Research, 27, 27-51.

Düring, B. S. (2011). The prehistory of Asia Minor: from complex hunter-gatherers to early urban societies. New York NY: Cambridge University Press.

Earle, T.K. (1997). How chiefs come to power: the political economy in prehistory. Stanford, Calif:: Stanford University Press.

Earle, T.K. (2017a). An essay on political economies in prehistory. Beiträge zur Wirtschaftsarchäologie Band 2. Graduiertenkolleg 1878. Bonn: Habelt.

Earle, T.K. (2017b). Property in prehistory. In M. Graziadei and L. Smith (Eds.), Comparative Property Law: Global Perspectives (pp. 3-25). Northampton, MA: Elgar. 
Earle, T.K. \& Spriggs, M. (2015). Political Economy in Prehistory: A Marxist Approach to Pacific Sequences. Current Anthropology, 56 (4), 515-44.

Earle, T., Ling, J., Uhnér, C., Stos-Gale, Z. \& Melheim, L. (2015). The Political Economy and Metal Trade in Bronze Age Europe: Understanding Regional Variability in Terms of Comparative Advantages and Articulations. European Journal of Archaeology, 18, 633657.

Erickson, C. (2006). Intensification, Political Economy, and the Farming Community; In Defense of a Bottom-Up Perspective of the Past. In J. Marcus \& C. Stanish (Eds.), Agricultural Strategies (pp. 334-63). Los Angeles: Cotsen Institute.

Finlayson, B. \& Makarewicz, C.A. (2017). The Neolithic of Southern Jordan. In Y. Enzel \& O. Bar-Yosef (Eds.), Quaternary of the Levant: Environments, Climate Change, and Humans (pp. 737-42). Cambridge: Cambridge University Press.

Fox, J.J. (1995). Austronesian Societies and Their Transformations. In P. Bellwood, J.J. Fox \& Tryon, D. (Eds.), The Austronesians: Historical and Comparative Perspectives. (pp. 214228). Canberra: Department of Anthropology, RSPacS, ANU.

Frirdich, C. (1994). Kulturgeschichtliche Betrachungen zur Bandkeramik im Merzbachtal. In J. Lüning \& P. Stehli (Eds.), Die Bandkeramik Im Merzbachtal Auf Der Aldenhovener Platte (pp. 207-394). Bonn: Rheinische Ausgrabungen.

Furholt, M. (2016). Settlement layout and social organisation in the earliest European Neolithic. Antiquity, 90 (353), 1196-1212. 
Furholt, M. (2017). Socio-spatial organisation and early Neolithic expansion in Western Anatolia and Greece. In M. Gori \& M. Ivanova (Eds.), Balkan Dialogues Negotiating Identity between Prehistory and the Present (pp. 111-130). Oxford: Routledge.

Furholt, M. (2018). Translocal Communities - Exploring Mobility and Migration in Sedentary Societies of the European Neolithic and Early Bronze Age. Praehistorische Zeitschrift, $92,304-321$.

Furholt, M., Bátora, J., Cheben, I., Kroll, H. \& Tóth, P. (2014). Vráble-Velké Lehemby: Eine Siedlungsgruppe der Linearkeramik in der Südwestslowakei. Vorbericht über die Untersuchungen der Jahre 2010 and 2012 und Deutungsansätze. Slovenská Archeológia, $62(2), 227-266$.

Furholt, M., Cheben, I, Mueller-Scheeßel, N., Müller, J., Bistakova, A, Wunderlich, M. (Eds). (in press). Archaeology in the Zitava valley 1 - The LBK settlement site of Vráble. Leiden: Sidestone Press.

Gilman, A. (1981). The Development of Social Stratification in Bronze Age Europe. Current Anthropology, 22(1), 1-23.

Gintis, H., van Schaik, C. \& Boehm, C. (2015). Zoon Politikon: The Evolutionary Origins of Human Political Systems. Current Anthropology, 56 (3), 327-53.

Graeber, D. (2004). Fragments of an Anarchist Anthropology. Chicago: Prickly Paradigm Press.

Graeber, D. (2014). On the moral grounds of economic relations: A Maussian approach. Journal of Classical Sociology, 14, 65-77. 
Grier, C. (2003). Dimensions of Regional Interaction in the Prehistoric Gulf of Georgia. In R. G. Matson, G. G. Coupland, \& Q. Mackie (Eds.), Emerging from the Mist: Studies in Northwest Coast Culture History (pp. 170-186). Vancouver, B.C.: University of British Columbia Press; London: Eurospan.

Grier, C. (2006). The Political Context of Prehistoric Coast Salish Residences on the Northwest Coast. In J. J. Christie and P. J. Sarro (Eds.), Palaces and Power in the Americas: From Peru to the Northwest Coast (pp. 141-65). Austin: University of Texas Press.

Grier, C. (2014). Landscape Construction, Ownership and Social Change in the Southern Gulf Islands of British Columbia. Canadian Journal of Archaeology, 38 (1), 211-49.

Grier, C. (2018). Comment on "Many Seasons Ago": Slavery and Its Rejection among Foragers on the Pacific Coast of North America, by David Wengrow and David Graeber. American Anthropologist, 120, 254-255.

Grier, C. \& Angelbeck, B. (2017). Tradeoffs in Coast Salish Social Action: Balancing Autonomy, Inequality, and Sustainability. In M. Hegmon (Ed.), The Give and Take of Sustainability: Archaeological and Anthropological Perspectives on Tradeoffs (pp. 198221) Cambridge: Cambridge University Press.

Grier, C., Angelbeck, B. \& McLay, E. (2017). Terraforming and Monumentality as Long-term Social Practice in the Salish Sea Region of the Northwest Coast of North America. Hunter Gatherer Research, 3(1), 107-132.

Gronenborn, D., Strien, H.-C., van Dick, R., and P. Turchin (2018). Social diversity, social identity, and the emergence of surplus in the western central European Neolithic. In H. Meller, D. Gronenborn, \& R. Risch (Eds). Surplus without the State. Political Forms in 
Prehistory. 10th Archaeological Conference of Central Germany October 19-21, 2017 in Halle (Saale) (pp. 201-220). Halle: Landesamt für Denkmalpflege und Archäologie in Sachsen-Anhalt, Landesmuseum für Vorgeschichte.

Hage, P. (1999a). Reconstructing Ancestral Oceanic Society. Asian Perspectives, 38(2), 200228.

Hage, P. (1999b). Linguistic Evidence for Primogeniture and Ranking in Proto-Oceanic Society. Oceanic Linguistics, 38(2), 366-375.

Halstead, P. (2006). What's Ours is Mine? Village and Household in Early Farming Society in Greece. Amsterdam: J. Enschedé.

Halperin, R. H., 1989. Ecological versus Economic Anthropology: Changing ,Place‘ versus Changing ,Hands'. Research in Economic Anthropology, 11, 15-41.

Hardt, M. \& Negri, A. (2004). Multitude: War and Democracy in the Age of Empire. New York: Penguin Press HC.

Hau'ofa, E. (2008). Our Sea of Islands. In E. Hau'ofa (Ed.) We are the Ocean: Selected Works (pp. 27-40). Honolulu: University of Hawaii Press.

Hayden, B. (1995). The Emergence of Prestige Technologies and Pottery. In W. K. Barnett and J.W. Hoopes (Eds.), The Emergence of Pottery. Technology and Innovation in Ancient Societies (pp. 257-65). Washington/London: Smithsonian Institution Press.

Heckbert, S. (2013). MayaSim: An Agent-Based Model of the Ancient Maya Social-Ecological System. Journal of Artificial Societies and Social Simulation, 16 (4), 11. 
Hodder, I. (2014). Integrating Catalhöyük: themes from the 2000 - 2008 seasons. Los Angeles, Calif:: Institute of Archaeology; London: British Institute at Ankara.

Hung, H.-C. \& Carson, M. T. (2014). Foragers, fishers and farmers: origins of the Taiwanese Neolithic. Antiquity, 88 (342), 1115-31.

Irwin, G. (1992) The Prehistoric Exploration and Colonisation of the Pacific. Cambridge: Cambridge University Press.

Jakucs, J., Bánffy, E., Oross, K., Voicsek, V., Bronk Ramsey, C., Dunbar, E., Kromer B., et al. (2016). Between the Vinča and Linearbandkeramik Worlds: The Diversity of Practices and Identities in the 54th-53rd Centuries Cal BC in Southwest Hungary and Beyond. Journal of World Prehistory 29 (3), 267-336.

Jonaitis, A. (1991). Chiefly Feasts: The Enduring Kwakiutl Potlatch. Seattle, New York: University of Washington Press.

Kienlin, T. L. \& Zimmermann, A. (2012). Beyond Elites - Alternatives to Hierarchical Systems in Modelling Social Formations: International Conference at the Ruhr-Universität Bochum, Germany. Bonn: Habelt.

Kirch, P. V. (1997). Microcosmic Histories: Island Perspectives on ,Global ${ }^{`}$ Change. American Anthropologist, 99 (1), 30-42.

Kirch, P.V. (2017). On the Road of the Winds: An Archaeological History of the Pacific Islands before European Contact. Revised and Expanded Edition. Berkeley: University of California Press. 
Kirch, P.V. \& Green, R.C. (2001). Hawaiki, Ancestral Polynesia: An Essay in Historical Anthropology. Cambridge: Cambridge University Press.

Kozłowski, J.K., \& Raczky, P. (2010). Neolithization of the Carpathian Basin. Northernmost distribution of the Starčevo/Körös culture. Papers on the symposium organized by the EU Projekt FEPRE. Kraków/Budapest: Polska Akademia Umiejętności Kraków.

Krause, R. (1998). Die bandkeramischen Siedlungsgrabungen bei Vaihingen an der Enz, Kreis Ludwigsburg (Baden-Württemberg). Berichte der Römisch-Germanischen Kommission, $79,5-106$.

Kristiansen, K. (2009). Household economy, long-term change and social transformation. The Bronze Age political economy of northwestern Europe. Scienze dell'Antichità, 15, 62131.

Kristiansen, K. (2010). Decentralized Complexity: The Case of Bronze Age Northern Europe. In Price T.D. \& Feinman, G.M. (Eds.), Pathways to Power (pp. 169-192) New York, NY: Springer.

Kropotkin, P. A., 1972. Mutual Aid; a Factor of Evolution. New York: Garland.

Kuijt, I. (2008). Demography and storage systems during the Southern Levantine Neolithic demographic transition. In J.P. Bocquet-Appel and Ofer Bar-Yosef (Eds.), The Neolithic Demographic Transition and Its Consequences (pp. 287-313). New York, NY: Springer.

Kuijt, I. \& Finlayson, B. (2009). Evidence for Food Storage and Predomestication Granaries 11,000 Years Ago in the Jordan Valley. Proceedings of the National Academy of Sciences, 106 (27), 10966-70. 
Lepofsky, D., Hallett, D., Washbrook, K., McHalsie, A., Lertzman, K. \& Mathewes, R. (2005). Documenting Precontact Plant Management on the Northwest Coast: An Example of Prescribed Burning in the Central and Upper Fraser Valley, British Columbia. In D.E. Deur and N.J. Turner (Eds.), Keeping It Living: Traditions of Plant Use and Cultivation on the Northwest Coast (pp. 218-39). Vancouver/Seattle: UBC Press/University of Washington Press.

Leppard, T. P. (2014). Mobility and migration in the Early Neolithic of the Mediterranean: questions of motivation and mechanism. World Archaeology, 46 (4), 484-501.

Lien, C. M. 1991. The Neolithic archaeology of Taiwan and the Peinan excavations. Bulletin of the Indo-Pacific Prehistory Association, 11, 339-52.

Lien, C. M. 2002. The Jade Industry of Neolithic Taiwan. Bulletin of the Indo-Pacific Prehistory Association, 22, 55-62.

Ling, J, Earle, T.K. \& Kristiansen, K. (2018). Maritime mode of production: Raiding and trading in Seafaring Chiefdoms. Current Anthropology, 59 (4), 488-524.

Lipson, M., Skoglund, P., Spriggs, M. et al.. (2018). Population Turnover in Remote Oceania Shortly after Initial Settlement. Current Biology, 28(7), 1157-1165.

Lüning, J. \& Stehli, P. (1994). Die Bandkeramik im Merzbachtal auf der Aldenhovener Platte. Bd. 36. Rheinische Ausgrabungen. Bonn: Habelt.

Lull, V., Herrada, R.C. \&Micó Pérez, R. (2011). El Argar and the beginning of class society in the Western Mediterranean. In Hansen, S., Müller, J. (Eds.), Sozialarchäologische Perspektiven: Gesellschaftlicher Wandel 5000-1500 v : Chr. Zwischen Atlantik Und 
Kaukasus. Internationale Tagung 15.-18. Oktober 2007 in Kiel (pp. 381-414) Mainz: Philipp von Zabern.

Makarewicz, C. A. (2013). A pastoralist manifesto: Breaking stereotypes and re-conceptualizing pastoralism in the Near Eastern Neolithic. Levant, 45 (2), 159-74.

Marciniak, A., Barański, M.Z., Bayliss, A., Czerniak, L., Goslar, T., Southon, J. \& Taylor, R.E. (2015). Fragmenting times: interpreting a Bayesian chronology for the Late Neolithic occupation of Çatalhöyük East, Turkey. Antiquity, 89 (343), 154-176.

Marshall, P. (1993). Demanding the Impossible: A History of Anarchism: Be Realistic! Demand the Impossible! New edition. London: Harpercollins Publishers.

McGuire, R. H. \& Saitta, D. J. (1996). Although They Have Petty Captains, They Obey Them Badly: The Dialectics of Prehispanic Western Pueblo Social Organization. American Antiquity, 61 (2), 197-216.

McIntosh, S. K. (Ed.), 1999. Beyond Chiefdoms: Pathways to Complexity in Africa. New Directions in Archaeology. Cambridge: Cambridge University Press.

Meadows, J., Müller-Scheeßel, N., Filipovic, D., Kirleis, W., Schroedter, T., Agerskov Rose, H., Cheben, I. \& Furholt, M. (in press) Temporal Transformations/dynamics of LBK Settlements, Houses and Human Impact on the Environment based on Bayesian Chronological Modelling of Radiocarbon Dates. The Holocene, accepted.

Miller, B. G. \& Boxberger, D.L. (1994). Creating Chiefdoms: The Puget Sound Case. Ethnohistory, 41, 267-293. 
Müller, J., Rassmann, K., \& Videiko, M. (2016). Trypillia mega-sites and European prehistory 4100-3400 BCE. London: Routledge.

Müller-Scheeßel, N., Cheben, I., Filipović, D., Hukel’ová, Z., \& Furholt, M. (accepted), The LBK site of Vráble/Southwest Slovakia: Results of the excavation season 2016. Berichte der Römisch-Germanischen Kommission.

Özdoğan, M. (1997). The beginning of Neolithic economies in southeastern Europe: an Anatolian perspective. Journal of European Archaeology, 5(2), 1-33.

Palumbi, G. (2012). The Arslantepe Royal Tomb and the "Manipulation" of the Kurgan Ideology in Eastern Anatolia at the Beginning of the Third Millennium. MOM Éditions, 58, 47-59.

Pawley, A., 1982 Rubbish-man commoner, big man chief? Linguistic evidence for hereditary chieftainship in Proto Oceanic society. In J. Siikala, (Ed.), Oceanic Studies: Essays in Honour of Arne A. Koskinen (pp. 33-52). Helsinki: The Finnish Anthropological Society.

Pawley, A. \& Green, R.C., 1973. Dating the dispersal of the Oceanic languages. Oceanic Linguistics, 12, 1-67.

Pels, P. (2010). Temporalities of ,religion` at Çatalhöyük. In I. Hodder (Ed.), Religion in the emergence of civilization: Çatalhöyük as a case study (pp. 220-67). Cambridge: Cambridge University Press.

Peterson, N. (1993). Demand Sharing: Reciprocity and the Pressure for Generosity among Foragers. American Anthropologist, 95 (4), 860-74.

Pétrequin, P. (2012). Jade : grandes haches alpines du Néolithique européen: Ve au IVe millénaires av. J.-C. Besançon: Presses Universitaires de Franche-Comté. 
Polanyi, K., 1957. The economy as instituted process. In K. Polanyi, C. Arensberg \& H. Pearson (Eds.), Trade and market in the early empires: Economies in History and Theory (pp. 243-69). Glencoe, Ill.: Free Press.

Posth, C., Nägele, K., Colleran, H. \& Powell, A. 2018. Language Continuity despite Population Replacement in Remote Oceania. Nature: Ecology and Evolution, 2 (April), 731-740.

Price, T.D. \& Bar-Yosef, O. (2010). Traces of Inequality at the Origins of Agriculture in the Ancient Near East. In Price, T.D. \& Feinman, G.M. (Eds.), Pathways to Power New Perspectives on the Emergence of Social Inequality (pp. 147-168). New York, NY: Springer.

Reingruber, A. (2011). Early Neolithic Settlement Patterns and Exchange Networks in the Aegean. Documenta Praehistorica XXXVIII Neolithic Studies 18: p.291-306.

Robb, J. (2013). Material culture, landscapes of action, and emergent causation: a new model for the origins of the European Neolithic. Current Anthropology 54(6): p.657-683.

Robb, J. E. \& Pauketat, T.R. (2013). Big Histories, Human Lives. In J. E. Robb \& T. R. Pauketat (Eds.), Big Histories, Human Lives: Tackling Problems of Scale in Archaeology (pp. 333. Santa Fe: School for Advanced Research Press.

Robin, C. (2013). Everyday life matters: Maya farmers at Chan. Gainesville: University Press of Florida.

Rosenstock, E. (2009). Tells in Südwestasien und Südosteuropa, Urgeschichtliche Studien. Remshalden: Greiner. 
Rosenstock, E., Franz, I., Orton, D., Anvari, J., \& Ostaptchouk, S. (2012). One Community and Two Tells: The Phenomenon of Relocating Tell Settlements at the Turn of the 7th and 6th Millennia in Central Anatolia. In R. Hofmann, F.-K. Moetz, \& J. Müller (eds.) Tells: Social and Environmental Space. Proceedings of the International Workshop "SocioEnvironmental Dynamics over the Last 12,000 Years: The Creation of Landscapes II (14th-18th March 2011)" in Kiel, 53-65. Bonn: Habelt.

Rowley-Conwy, P. (2001). Time, Change and the Archaeology of Hunter-Gatherers: How Original Is the ,Original Affluent Society“? In C. Panter-Brick, R. H. Layton \& P. Rowley-Conwy (Eds.), Hunter-Gatherers: An Interdisciplinary Perspective (pp. 39-72). Cambridge: University Press.

Sahlins, M. D. (1958). Social Stratification In Polynesia. Seattle: University Of Washington Press.

Saitta, D. J. \& McGuire, R.H. (1998). Dialectics, Heterarchy, and Western Pueblo Social Organization. American Antiquity, 63 (2), 334-36.

Sastre, I., \& Sánchez-Palencia, F.J. (2013). Nonhierarchical Approaches to the Iron Age Societies: Metals and Inequality in the Castro Culture of the Northwestern Iberian Peninsula. In Cruz, M., García, L., \& Gilman, A (Eds.). The Prehistory of Iberia: Debating Early Social Stratification and the State, (pp. 292-310). London: Routledge.

Schaepe, D. (2009). Pre-Colonial Sto:Lo-Coast Salish Community Organization: An Archaeological Study. Unpublished PhD Dissertation, Vancouver, B.C.: University of British Columbia. 
Scott, J. (1976). The moral economy of the peasant: rebellion and subsistence in Southeast Asia. New Haven: Yale University Press.

Scott, J. (1985). Weapons of the weak: Everyday forms of peasant resistance. New Haven: Yale University Press.

Scott, J. (2017). Against the grain. New Haven: Yale University Press.

Shanks, M., \& Tilley, C. (1991). Social Theory and Archaeology. Albuquerque: University of New Mexico Press.

Skoglund, P., Posth, C., Sirak,C., Spriggs, M., Valentin, F., Bedford, S., Clark, G.R., et al. (2016). Genomic Insights into the Peopling of the Southwest Pacific. Nature, 538 (27 October), 510-513.

Souvatzi, S.G. (2008). A Social Archaeology of Households in Neolithic Greece. An Anthropological Approach. Cambridge: University Press.

Spriggs, M. (2010). Geomorphic and archaeological consequences of human arrival and agricultural expansion on Pacific Islands: a reconsideration after 30 years of debate. In S. Haberle, J. Stevenson \& M. Prebble (Eds.), Altered Ecologies: Fire, Climate and Human Influence on Terrestrial Landscapes. Papers in Honour of Geoff Hope (pp. 239-252). Canberra: ANU E Press.

Spriggs, M. (2011). Archaeology and the Austronesian expansion: where are we now? Antiquity, 85 (328), 510-28. 
Spriggs, M. (2016). Thoughts of a Comparativist on Past Colonisation, Maritime Interaction and Cultural Integration. In L. Melheim, H. Glørstad \& Z. Tsigaridas Glørstad (Eds.), Comparative Perspectives on Past Colonisation, Maritime Interaction and Cultural Integration (pp. 271-80). Sheffield, Bristol: Equinox Publishing Ltd.

Stanish, C. (2017). The Evolution of Human Co-operation: Ritual and Social Complexity in Stateless Societies. Cambridge: Cambridge University Press.

Suttles, W. (1960). Affinal Ties, Subsistence, and Prestige among the Coast Salish. American Anthropologist 62, (2), 296-305.

Todorova, H. (1978). The Eneolithic in Bulgaria. Oxford: University Press.

Tong, L.-T. T., Lee, K.-H., Yeh, C.K., Huang, Y.-T. \& Liu, C.-Y. (2013a). Ground-Penetrating Radar Prospecting in the Peinan Archaeological Site, Taiwan. Terrestrial, Atmospheric \& Oceanic Sciences, 24 (3), 311-21.

Tong, L.-T. T., Lee, K.-H., Yeh, C.K., Hwang, Y.-T. \& Chien, J.-M. (2013b). Geophysical study of the Peinan Archaeological Site, Taiwan. Journal of Applied Geophysics, 89 (February), 1-10.

Valentin, F., Herrscher, E., Bedford, S., Spriggs, M. \& Buckley, H. (2014). Evidence for Social and Cultural Change in Central Vanuatu Between 3000 and 2000 BP: Comparing Funerary and Dietary Patterns of the First and Later Generations at Teouma, Efate. The Journal of Island and Coastal Archaeology, 9 (3), 381-99.

Wengrow, D. \& Graeber, D. (2015). Farewell to the ,childhood of man': ritual, seasonality, and the origins of inequality. Journal of the Royal Anthropological Society, 21 (3), 597-619. 
Wengrow, D. \& Graeber, D. (2018). "Many Seasons Ago": Slavery and Its Rejection among Foragers on the Pacific Coast of North America. American Anthropologist, 120, 237-249.

Widlok, T. (2016). Anthropology and the Economy of Sharing. Abingdon,; New York, NY: Oxon.

Wilson, P. J. (1991). The domestication of the human species. New Haven: Yale University Press.

Woodburn, J., 1982. Egalitarian Societies. Man, 17 (3), 431-51.

Wright, K.I. (2014). Domestication and inequality? Households, corporate groups and food processing tools at Neolithic Çatalhöyük. Journal of Anthropological Archaeology, 33, $1-33$.

Younger, J.G. \& Rehak, P. (2008). Minoan Culture: Religion, Burial Customs, and Administration. In C.W. Shelmerdine, (Ed.), The Cambridge Companion to the Aegean Bronze Age (pp. 165-185). Cambridge: University Press.

Zilhão, J. (2000). From the Mesolithic to the Neolithic in the Iberian Peninsula. In T. D. Price (Ed.), Europe's first farmers, (pp. 144-182). New York: Cambridge University Press.

Zvelebil, M. \& Pettitt, P. (2013). Biosocial archaeology of the Early Neolithic: Synthetic analyses of a human skeletal population from the LBK cemetery of Vedrovice, Czech Republic. Journal of Anthropological Archaeology, 32, 313-329. 
Figure Captions

Fig. 1 Map of the American North West Coast showing the Coast Salish region.

Fig. 2 Map of Europe showing the gradual expansion of Neolithic ways of life, and halt lines, as discussed in the text.

Fig. 3 Geomagnetical plan of the LBK site of Vráble, with interpretative features.

Fig. 4 Map of Southeast Asia showing islands and sites mentioned in the text. Map by Catherine Fitzgerald and Matthew Spriggs.

Fig 5. The distribution of the Lapita Culture in the Western Pacific. Map courtesy Stuart Bedford. 